\title{
When Will Greece Get its Money back from Germany? Reflections on Yanis Varoufakis' New Book
}

\section{Christian Fuchs}

University of Westminster: Communication and Media Research Institute (CAMRI); Westminster Institute for Advanced Studies. London, UK, christian.fuchs@uti.at, http://fuchs.uti.at, http://www.westminster.ac.uk/camri, http://www.westminster.ac.uk/wias, @fuchschristian

Abstract: This article reviews Yanis Varoufakis' book "And the Weak Suffer what They Must? Europe, Austerity and the Threat to Global Stability". It argues that the question "When will the creditors get 'their money' back from Greece?" must be dialectically reversed: When will Greece get its money back from Germany? When will Germany pay its debts?

Keywords: Yanis Varoufakis, Europe, Greece, EU, crisis, capitalism, austerity

Yanis Varoufakis: And the Weak Suffer what They Must? Europe, Austerity and the Threat to Global Stability. London: The Lane, 2015, 368 pages. ISBN 978147924032 (hardback), ISBN 9781847924049 (paperback)

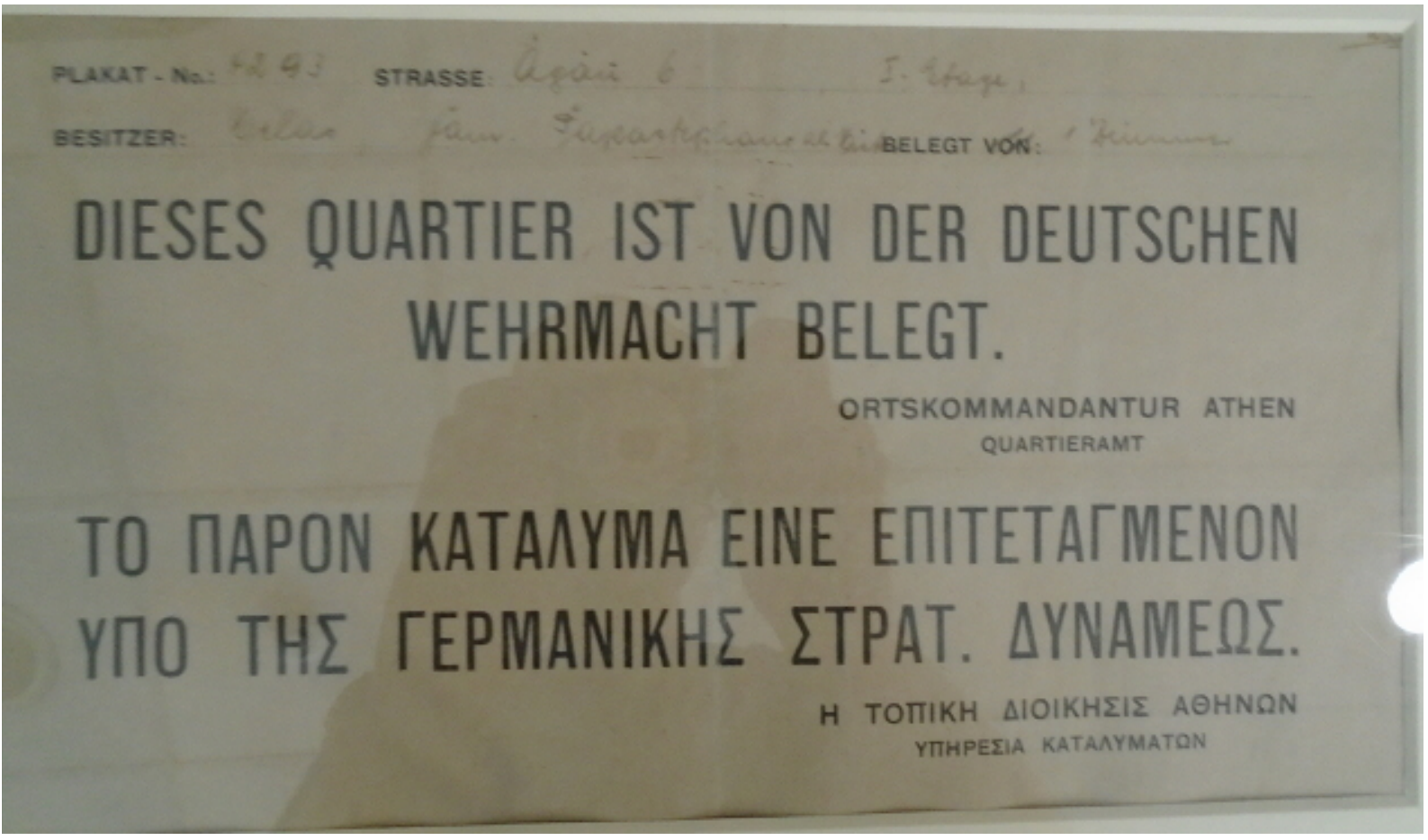

Yanis Varoufakis' book And the Weak Suffer what They Must? Europe, Austerity and the Threat to Global Stability tells the history of the Eurozone and its crisis. It is a history of the relation of German, French and US interests in the world economy. The former Greek finance minister narrates economic stories of how the powerful make the weak suffer and how they trample upon them.

Varoufakis uses a metaphorical and provocative language that evokes Greek mythology. He presents global capitalism as a timeless beast and a global Minotaur. The book shows 
that the Eurozone was born and has developed in the midst of high-risk financialisation and neoliberalism. Varoufakis' reconstruction makes clear that Germany largely controls the Eurozone. He analyses how Germany with brute Teutonic financial force ignored Greek protests and democratic referenda calling for debt restructuring. It becomes evident that the Greek "bailouts" were in fact "rescue packages for French and German banks" (158) and that the troika's "fiscal waterboarding" (160) of the Greek state has had devastating social consequences. Greece is an austerity laboratory that is used for sending threats to the rest of Europe about what may happen if one attempts to practice socialism or any resistance against neoliberalism.

For Varoufakis, the current EU is a "technocracy" that "eradicated the type of political leadership necessary to step in during a crisis" (93). It is an undemocratic mega-bureaucratic machine serving corporate interests, a Europe of states and not of citizens (101). Varoufakis' conclusion is that the EU shouldn't be smashed, as Grexiters, Brexiters and other Eurosceptics tend to suggest, but democratised. He suggests to implement a European New Deal that he calls "decentralised Europeanisation". The former Greek finance minister warns that Europe may slide into totalitarianism and says that it looks like "2008 is our version of 1929" (8). This political threat does not just entail the possibility of the rise of fascism, but also something that Varoufakis only points at indirectly without naming it - a new world war.

Christos Laskos and the current Greek finance minister Euclid Tsakalotos argue in their book The Crucible of Resistance: Greece, the Eurozone and the World Economic Crisis (Laskos and Tsakalotos 2013) that Greece's problem is a combination of neoliberalism and its status as a peripheral country in Europe. Greek neoliberalism is a combination of a clientelistic state and oligarchic capitalist interests that favours tax evasion. Greece's economic problem is not government expenditure, but the lack of state income from capital taxation. Greece's productivity has been higher than the one of Germany, but it is "German restrictive wages policy after 2000 that made it almost impossible for the periphery to compete" (Laskos and Tsakalotos 2013, 83). Wage repression and export-orientation have produced trade surpluses for Germany (and other countries in the Eurozone such as Austria, Belgium, Finland, Luxembourg and the Netherlands) and growing trade deficits in Southern European Countries, including Greece. Northern and central European banks financed these deficits by providing loans to private and public borrowers that were supported by low interest rates set by the European Central Bank.

In contrast to his successor Tsakalotos, Varoufakis hardly uses macro-economic data, graphs and economic crisis theory, which is one of the reasons why the stories in And the Weak Suffer what They Must? are much less convincing than the analysis presented in The Crucible of Resistance. Whereas Tsakalotos' book was at the time of the writing of this piece ranked on sales position 641,336 on Amazon UK, Varoufakis' new bestseller held rank 22. Tsakalotos other than Varoufakis avoids being a media personality and turning left-wing politics into a spectacle. In the world of media spectacles, the levels of public attention and analytical quality often diverge.

Although devoid of data and theory, Varoufakis partly shares Laskos and Tsakalotos' analysis of the crisis. The main focus of Varoufakis is, however, on international commodity and financial market trade, i.e. the realm of circulation. Laskos and Tsakalotos in contrast more foreground wage repression in Germany and beyond. They focus on the analysis of class and the relations of production. The difference that makes a difference is that Varfoukis is other than Tsakalotos not a Marxian but a Keynesian economist.

Varoufakis contrasts events in the past with those in the present in order to show how those in power betray their own history when necessary for enforcing their interests. One of these powerful comparisons is that the 1953 London Debt Agreement largely cancelled Germany's war debts, whereas Germany today resists any haircut of Greece's debt. "When am I getting my money back?" (see p. 6), a German junior minister asked Varoufakis at the first meeting with the German finance minister Wolfgang Schäuble. 


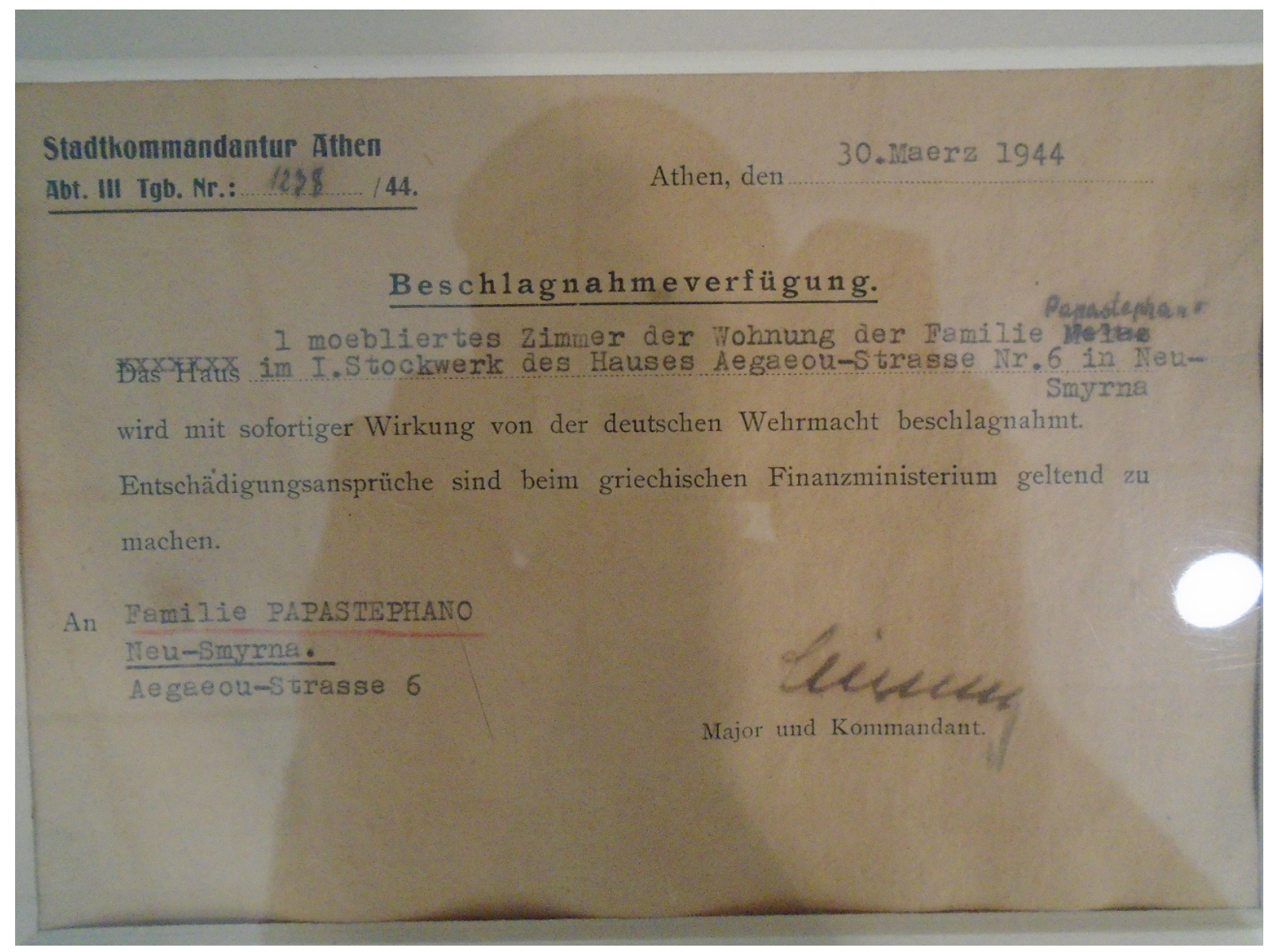

When Nazi Germany occupied Greece in 1941, it forced an interest-free loan on its new colony. This loan was never paid back. LSE economics professor Albrecht Ritschl argues that Germany's Nazi debt to Greece today has a value of over $€ 2$ trillion euros (Nevradakis 2014). Greece's outstanding gross debt is in 2016 around $€ 320$ billion (data source: AME$\mathrm{CO}$ ). Given Greece's debt payments and austerity measures, its economy will not be able to recover without a debt relief, but will stay in constant recession. Also the International Monetary Fund, one of the creditors, other than the European Commission acknowledges this fact: "Greece's debt can now only be made sustainable through debt relief measures that go far beyond what Europe has been willing to consider so far" (IMF 2015).

Syriza and Varoufakis missed the opportunity to publicly and in the 2015 negotiations with the troika foreground Germany's historical guilt and moral responsibility to pay back its Nazi debts to Greece. It should have reversed the question and should have asked: When will Germany pay back its debt to Greece? When will we get our money back from Germany? Varoufakis for example did not make use of this opportunity on March 15, 2015, in the Günther Jauch Show, a programme on the German public service TV station ARD with an average audience of 5 million. Asked about Germany's Nazi debt to Greece, Varoufakis answered that this issue should be kept separate from the one of the Greek debt.

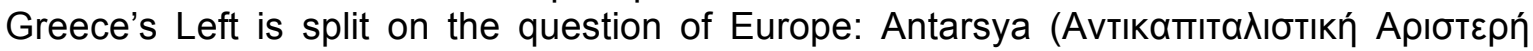

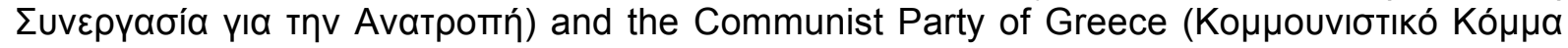

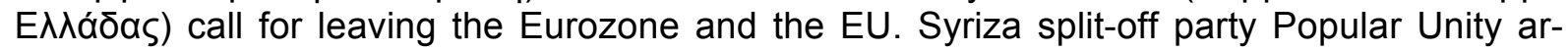
gues that Greece should leave the Eurozone and re-introduce the drachma. Syriza says that the crisis can only be tackled at the supranational and European level together with other left-wing movements and parties. Anti-EU and anti-Eurozone positions are often based on the assumptions that the problem is that Europe's centre exploits the Southern periphery and that socialism in one country is possible today. Syriza members and economists such as Euclid Tsakalotos criticise that this position sees an economic contradiction between nation states, not a class contradiction between capital and labour at the heart of the crisis. It mis- 
takenly assumes that "there are no class relations within northern economies" (Laskos, Milios and Tsakalotos 2012, 2).

Varoufakis' view has come closer to the one of Popular Unity (^aїкń Evótnтa). He writes in his book that Greece should have refused agreeing to austerity measures and should have risked being pushed "out of the Eurozone" (143). In an interview, he said that Tspiras "betrayed the 62\% of Greeks" (Varoufakis 2015) who voted "No" in the July 2015 bailout referendum. Varoufakis and others tend to blame the victim, who had a German financial gun pointed at his head with the threat "Sign! Or we will shoot dead your economy!". The myth of Alexis Tsipras the traitor, who over night is said to have turned into a neoliberal, is an ideology that distracts attention from Schäuble \& Co. as the political executioners driven by capitalist interests. Europe faces the combination of authoritarian neoliberalism, German financial imperialism, right-wing extremist refugee politics, and the strengthening of the far right. In such a situation, the split of progressive forces is a tactical mistake that helps their enemies.

Euclid Tsakalotos in contrast to Varoufakis argues that it is "too simplistic to say that Syriza failed because they did not leave the Euro" (Tsakalotos 2015b). Abandoning the Euro would have resulted in "another devil's decade" in Southern Europe that would especially have affected the poorest. After Syriza's "tactical compromise", a "more radical strategy", in which the Left unites beyond Greece would be needed. Tsakalotos (2015a) argues that the task of a left-wing finance minister is to enable "space for alternative experiments" in the solidarity economy and to challenge the aspects of the bailout deal that are unacceptable. Syriza would continue to struggle for debt relief. In this respect, Varoufakis (2015) agrees that "the Left will come back".

\section{The struggle continues!}

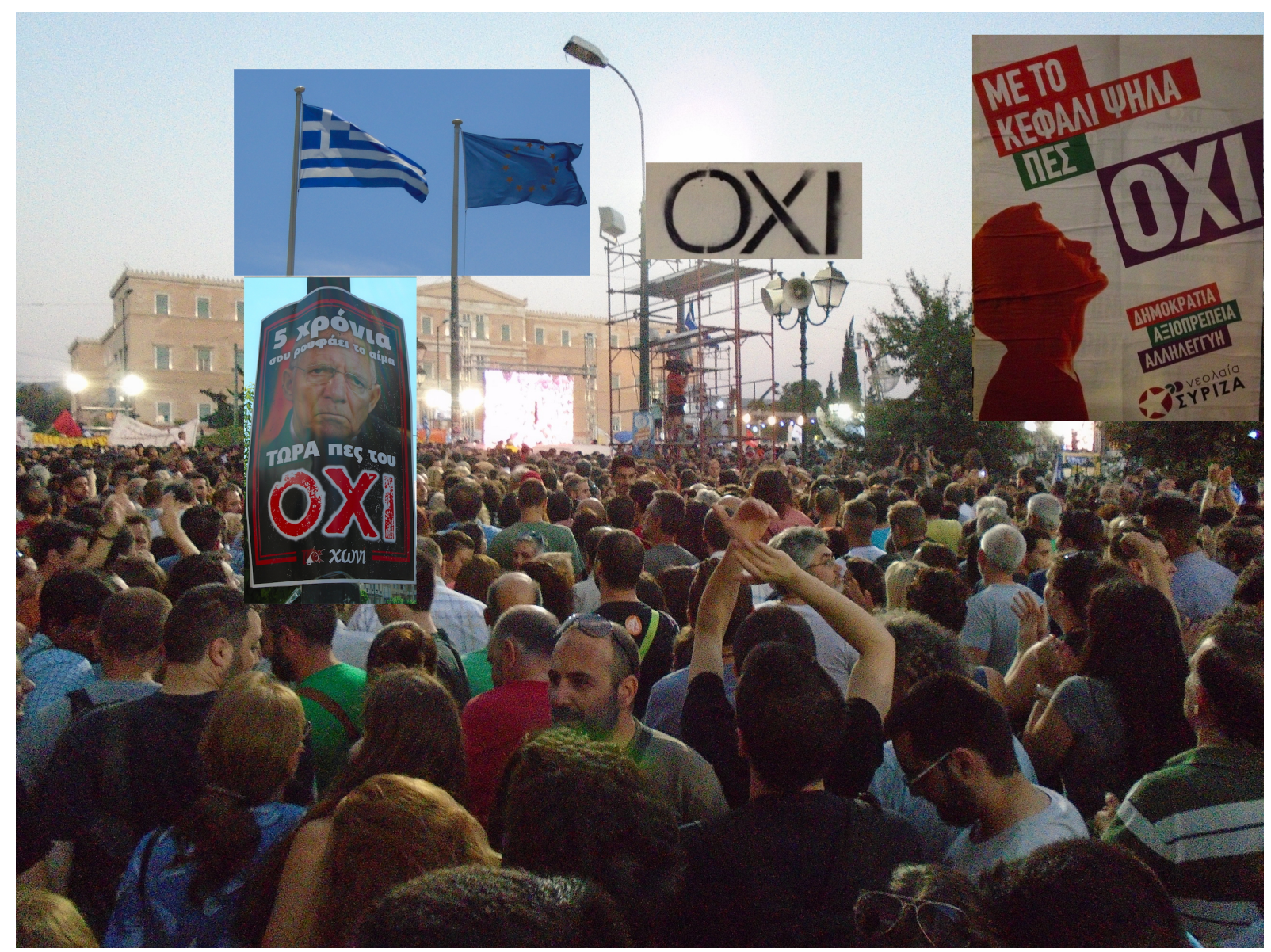




\section{References}

International Monetary Fund (IMF). 2015. Greece: An Update of IMF Staff's Preliminary Public Debt Sustainability Analysis. https://www.imf.org/external/pubs/ft/scr/2015/cr15186.pdf (accessed on April 12, 2015).

Laskos, Christos, John Milios and Euclid Tsakalotos. 2012. Communist Dilemmas on the Greek EuroCrisis: To Exit or Not to Exit? http://www.workersliberty.org/system/files/milios.pdf (accessed on April 12, 2015).

Laskos, Christos and Euclid Tsakalotos. 2013. Crucible of Resistance: Greece, the Eurozone \& the World Economic Crisis. London: Pluto.

Tsakalotos, Euclid. 2015a. Economic Blues: The Left in Government Times. Talk at the LSE. November 10, 2015. https://www.youtube.com/watch?v=eW8FyhyUNOw (accessed on April 12, 2015).

Tsakalotos, Euclid. 2015b. Interview. https://www.youtube.com/watch?v=L6YNII8T4RE\&nohtml5=False (accessed on April 12, 2015).

Nevradakis, Michael. 2014. Germany's Unpaid Debt to Greece: Economist Albrecht Ritschl on WWII Reparations that Never Were. http://www.truth-out.org/news/item/27261-germany-s-unpaid-debt-togreece-albrecht-ritschl-on-germany-s-war-debts-and-reparations (accessed on April 12, 2015).

Varoufakis, Yanis. 2015. Interview. https://www.youtube.com/watch?v=l14C7TCX_8A\&nohtml5=False (accessed on April 12, 2015).

\footnotetext{
About the Author

Christian Fuchs

Christian Fuchs is co-editor of the open access journal tripleC: Communication, Capitalism \& Critique (http://www.triple-c.at). He is a professor at the University of Westminster, where he is the Director of the Communication and Media Research Institute (http://www.westminster.ac.uk/camri) and the Director of the Westminster Institute for Advanced Studies (http://www.westminster.ac.uk/wias). He is a member of the European Sociological Association's Executive Committee. His books include "Critical Theory of Communication: New Readings of Lukács, Adorno, Marcuse, Honneth and Habermas in the Age of the Internet" (2016, forthcoming), "Reading Marx in the Information Age: A Media and Communication Studies Perspective on Capital Volume 1" (2016), "Culture and Economy in the Age of Social Media" (2015), "Digital Labour and Karl Marx" (2014), "Social Media: A Critical Introduction" (2014), "OccupyMedia! The Occupy Movement and Social Media in Crisis Capitalism" (2014), "Foundations of Critical Media and Information Studies" (2011), "Internet and Society: Social Theory in the Information Age" (2008). He is the author of around 300 academic works in the fields of critical theory and the critique of the political economy of communications, digital media, the Internet, social media and the information society.

http://fuchs.uti.at

@fuchschristian
} 